unless extracted and framed. A map of such general interest might well have been issued on paper of such a quality that it would stand up to use in the field by the investigator and by the amateur when travelling about the country. But it is a fine piece of work, and it will be a long time before another revise is needed.

\section{Distribution of Prehistoric Rock Engravings and Paintings in South Africa}

AN up-to-date gazetteer of all the sites in the Union of South Africa and South West Africa where rock-shelter paintings and engravings on rocks occur was prepared by the late Prof. C. van Riet Lowe and has been published by the Archæological Survey of the Union under the title: "Distribution of Prehistoric Rock Engravings and Paintings in South Africa" (Archæological Series No. 7. Pp. 58. Johannesburg : Union Education Department, 1956; 10s.). The arrangement is by provinces and districts, which makes it easy to use, especially as there is a foreword where the various groups are described. The publication will be very useful to prehistorians visiting South Africa and wishing to study a number of painted and engraved sites. There is an excellent distribution map.

\section{Measuring the Load on Pit Props}

From the earliest days of mining the support of the roof of the tunnel driven has been a question of the first importance. With the ordinary handwork at the pit face, it had come to be accepted in Western Europe that the coniferous pit prop was the safest that could be obtained, as it gives warning before breaking to collapse. Metal substitutes have had a brief trial; but they give no such warning. The successful development of mechanized systems of mining have brought other difficulties, and the wooden coniferous pit prop is no longer free from suspicion. This matter is dealt with in Science Bulletin No. 4 (Spring 1955) of the Scientific Department, National Coal Board (pp. 24; from the Board, London). Some sound roof control is of paramount importance, if mechanized systems of mining are to be introduced and accepted, to prevent falls of the roof on the coal face, and also to improve the workability of the coal seam. Attempts have been made in the past to undertake a complete study of roof control, entailing the measurement of the forces acting actually within the coal and the surrounding strata, but considerable problems are involved. Information can, however, be obtained from a study of the movements of the roof supports and of the loads they carry. For example, a study of the loads carried by the front row of props will help to show whether a prop-face front can be used. An instrument, called a load cell, has been devised which will register the load carried by a prop when placed between the prop and a roof bar. The load cell is small and robust, so that it can be set easily and will not interfere with the normal behaviour of the prop, and already it has been used for a number of investigations.

\section{Seismic Observations on a Large Explosion in North-East Japan}

ON September 13, 1953, at 3h. 4m. 57.074s., the second large explosion at the Kamaisi mine of the Nippon Iron Works (lat. $39^{\circ} 17^{\prime} 39 \cdot 9^{\prime \prime}$ N., long. $141^{\circ} 41^{\prime} 32 \cdot 9^{\prime \prime} \mathrm{E}$.) to be observed seismically occurred, this being the fifth explosion to be observed seismic- ally by the Japanese Research Group for Explosion Seismology (Bull. Earthquake Res. Inst., Tokyo Univ., 33, Pt. 4, 699; December 1955). The aim of the blasting operation was to remove dangerous gangue rocks as a safety measure, and the letting off of 42 tons of explosives was operated in seven steps, which took altogether 84 milliseconds from first to last. From a seismic point of view, this method is less effective than if the whole mass had been let off at once. Fourteen seismograph stations for refraction shooting were placed from near the shot point to a distance of $332 \mathrm{~km}$., the most sensitive instruments being placed $170-332 \mathrm{~km}$. distant. Most of the seismographs used were vertical electromagnetic instruments, working at $3 \mathrm{c} / \mathrm{s}$., though the nearest worked at $10 \mathrm{c} . / \mathrm{s}$. , and an additional one at the most distant station worked at $0 \cdot 7 \mathrm{c} / \mathrm{s}$. Horizontal electromagnetic seismographs were operating at six stations, working either at $3 \mathrm{c} . / \mathrm{s}$. ox $1 \mathrm{c} . / \mathrm{s}$. The line of fourteen stations was almost parallel with, and near, the east coast line from about lat. $36^{\circ} 33^{\prime} \mathrm{N}$. to about lat. $39^{\circ} 18^{\prime} \mathrm{N}$. In addition, a special station was established at Umanokiuti $(\Delta=4.63 \mathrm{~km}$.) to make observations of reflected waves. $P$ - and $S$-wave onsets were read at most stations, and travel-time curves constructed from the results. On the assumption of horizontally disposed layers, the $P$-wave indicated a layer of thickness between 22 and $25 \mathrm{~km}$. in which the velocity was $6.05 \mathrm{~km}$. $/ \mathrm{sec}$, overlying a layer in which the velocity of $P$-waves was $7 \cdot 2-7 \cdot 6$ $\mathrm{km}$./sec. Reflexion experiments tended to confirm this thickness for the upper layer. Results from the $S$-wave alone gave a thickness of between 32 and $36 \mathrm{~km}$. for the upper layer in which the velocity of the $S$-wave was $3.46 \mathrm{~km}$. $/ \mathrm{sec}$, overlying a stratum in which the velocity of the $S$-wave was between 4.5 and $4.8 \mathrm{~km}$. $/ \mathrm{sec}$. The discrepancy in the estimate of thickness of the upper layer may be due to the influence of a more complicated structure than that assumed. This is to be investigated.

\section{Scientific Instrument Manufacturers' Association : Officers for 1956-57}

THE following have been elected officers for 195657 of the Scientific Instrument Manufacturer's' Association: President, G. A. Whipple (Hilger and Watts, Ltd.) ; Vice-President, P. Goudime (Electronic Instruments, Ltd.); Honorary Secretary, J. E. C. Bailey (Baird and Tatlock (London), Ltd.); Honorary Treasurer, C. H. Warner (W. F. Stanley and Co., Ltd.); Nєw Members of Council, F. W. Dawe (Dawe Instruments, Ltd.), P. J. Ellis (R. B. Pullin and Co., Ltd.), J. M. Furnival (Marconi Instruments, Ltd.), D. F. Newstead (Kershaw Division, Rank Precision Industries, Ltd.), J. A. Stafford (Taylor, Taylor and Hobson, Ltd.), W. H. Storey (Unicam Instruments, Ltd.) and N. Trepte (Griffin and George, Itd.).

\section{University of London}

Dr. L. A. Elson, British Empire Cancer Campaign Intermediate Research Fellow, has been appointed to the University of London readership in biochemistry tenable at the Institute of Cancer Research, Royal Cancer Hospital, London. The title of professor of experimental pathology (histopathology) in the University of London has been conferred on Dr. E. S. Horning, in respect of his post at the Institute of Cancer Research, Royal Cancer Hospital, and that of reader in physical organic chemistry in the 